\title{
Managing through a crisis: Effects of nCovid 19 and the significance of organisational slack resources in strategic agility.
}

\section{A case of Zimbabwe Tourism and Hospitality Industry}

\author{
Simbarashe Nhokovedzo *, Tawanda Prosper Mushayavanhu ${ }^{* *}$, Kudzai Ziki ${ }^{* *}$ \\ * Technopreneurship Development Centre, Harare Institute of Technology
}

DOI: 10.29322/IJSRP.10.11.2020.p10785

http://dx.doi.org/10.29322/IJSRP.10.11.2020.p10785

\begin{abstract}
This study examined the effects of nCovid 19 on the Tourism and Hospitality firms and assessed the significance of organisational slack resources in mitigating these effects. Research data obtained from 260 respondents was analysed statistically. The findings depicted some debilitating effects of the pandemic on business key performance indicators. More critically, analysis showed the essence of organisational slack resources in ameliorating the effects of pandemic on the business. Organizations with slack resources at their disposal were found to be more agile in face of an operational jolt posed by nCovid 19 . Firms were recommended to maintain an optimum threshold of absorbed and unabsorbed slack resources. Robust corporate strategies such as organisational ambidexterity were suggested to foster dexterity of firms when faced with vagaries of the dynamic operating environment
\end{abstract}

Index Terms- absorbed slack resources, nCovid 19 pandemic, strategic agility, tourism, unabsorbed slack resources,

\section{INTRODUCTION}

The outbreak of novel Covid-19, a special type of the Corona virus has disrupted the normal flow of business at a global level. The virus, first discovered in the Chinese city of Wuhan in December 2019, spreads to become a global pandemic. By September 2020, it had claimed over a million lives globally. The virus has brought unprecedented direct and indirect afflictions on humanity. As researchers in various fields such as microbiology, epidemiology and medicine continue to explore solutions, the virus continue to wreak havoc on the business front imposing the "new normal of doing business". The novelty of the virus calls for research to examine and quantify its impact on business operations. The key test was on the role played by organisational slack resources on the responsive of businesses when faced with a crisis like the one brought by nCovid-19. In various countries, available literature shows attempts that have been made to assess the impact of the pandemic in different spheres of life. Historically, pandemics have often disrupted business operations as evidenced by the various studies that explored the implications of the Spanish Flu of 1918. Swift (2009) acknowledged that measuring the full impact of the Spanish Flu was difficult due to the cofounding war effects as European countries were just emerging from the First World War. Nonetheless, the number of deaths confirmed that this was indeed a very serious pandemic. With regard to business operations, it has been noted that pandemics usually affect both supply and demand variables in the markets Swift (2009). In the same vein, Qiu, Rutherford, Mao and Chu (2017) admitted that during pandemics there is always a sharp decline in the number of hours committed to productive work. The major drivers in the decline in hours of work include a fall in aggregate demand, illness and fear of infections. The paper categorically explored effects of Covid-19 on business operations and the role of slack resources in managing agility among players in the tourism and hospitability sector in Zimbabwe. A number of variables were used to measure the implications of Covid-19 on the business operations and these included variances in effective and nominal demand, revenue inflows, working capital, supply chain operations and operating profit. As the country recorded a steady growth in infections from both foreign transmissions and local transmissions, the government of Zimbabwe imposed the World Health Organization prescribed lockdown which shutdown the entire country. The study analyses were confined within the time limit of February to September 2020, which is dubbed the first peak period of Corona virus in Zimbabwe. 


\section{Literature review}

What is a pandemic?

Honigsbaum (2009) defined a pandemic as a wide spread epidemic of contagious diseases throughout a country, continent or the whole globe. The medicineNet (visited on 20 September 2020) traces the meaning of the term pandemic from its Greek roots, "pan-" for all + "demos" for all people or population = "pandemos" to mean all people. This means that in a pandemic all people are affected. On the contrary, Honigsbaum (2009) defined an epidemic as an outbreak that spreads throughout an area where the disease was not previously known. From the two definitions, the corona virus is an epidemic, which has become a pandemic. The World Health Organization declared that Corona Virus is a world pandemic on 30 January 2020 (WHO Report, 2020).

\section{Effects of pandemics on business operations}

Literature is awash with information on the impact of pandemics on the structure and performance of businesses at a country, regional and world level. Before the novel Corona virus, the influenza pandemic of 1918, termed the Spanish Flu'1 had the most catastrophic effects in the modern historic times. In a report by Garrett (2008), the Spanish Flu'1 killed over 40 million people worldwide from the early spring of 1918 through to late spring of 1919. Furthermore, documentary analysis suggested that firms in the United States saw their businesses declining by between 40 to 70\% during the Spanish flue era (Garrett (2007, 2008). Apart from the Spanish Flue, Rassy and Smith (2013) documented the impact of Swine Flu that was commonly known as H1N1 on the Mexican tourism and pork industries in 2009.Rassy and Smith (2013) noted the debilitating impact of H1N1, which led to a serious decline in the poultry sector in South America. In 2010 the World Health Organisation reported that over 18000 fatalities were confirmed from H1N1. This was believed to the reason for Mexican tourism industry failure to recover from the global economic crisis of 2008. In a separate study, Brown and Smith (2008) analysed the macro economic impact of the 2003 Severe Acute Respiratory Syndrome (SARS) which affected approximately 10000 people across the globe and their submissions brought a better understanding of the need for a concerted effort when dealing with pandemics of this magnitude. A crosssectional assessment of the previous pandemics and their impact on the operations of businesses can be closely related to the current nCovid-19 pandemic in terms of the impact on businesses performance. (Fernandes 2020). The UNDP (2020) posited Zimbabwe's tourism sector as the key sector generating around US\$1, 4 billion that is about $3.3 \%$ of the economy. UNDP (2020:10) recorded that tour operators and hotels in the resort city of Victoria Falls for instance had reported 80 percent cancellations of business by early March 2020 and most hotels reduced business significantly leading to loss of jobs and income.

\section{Zimbabwean Tourism and Hospitality nCovid 19 pandemic antecedents}

Prior to nCovid 19, Zimbabwean Tourism and Hospitality sector had its own challenges.

Abel and Roux (2017) observed sectorial challenges associated with the issue of licenses, taxation and statutory fees. Various taxes were levied across the entire industry right from tour operators, transporters, air operators and hotels. The taxes include service tax, tax on transportation, aviation fees, operator's fees to local authorities and relevant government departments. According to Abel and Roux (2017), the majority of the levies are levied for similar things but paid to different government departments. The Sunday News of 16/07/2017 reported a host of challenges faced by tourists visiting Zimbabwe as revealed by a tourist exit survey. The mentioned challenges include poor infrastructure, harassment at port of entry and high prices of services at the Zimbabwean destination. Kurambakuwa, Mudavanhu, Mauchi and Chingarande (2015) echoed similar sentiments noting inability of tourist to access some resorts due to lack of domestic air connectivity, poor rood network and unreliable railway network. All these factors weighed down tourism business prior to nCovid 19. 
Other factors which negatively affected tourism included political instabilities, negative media publicity, economic problems and fuel shortages as shown by the below figure.

Figure 1.0 Factors affecting tourism in Zimbabwe

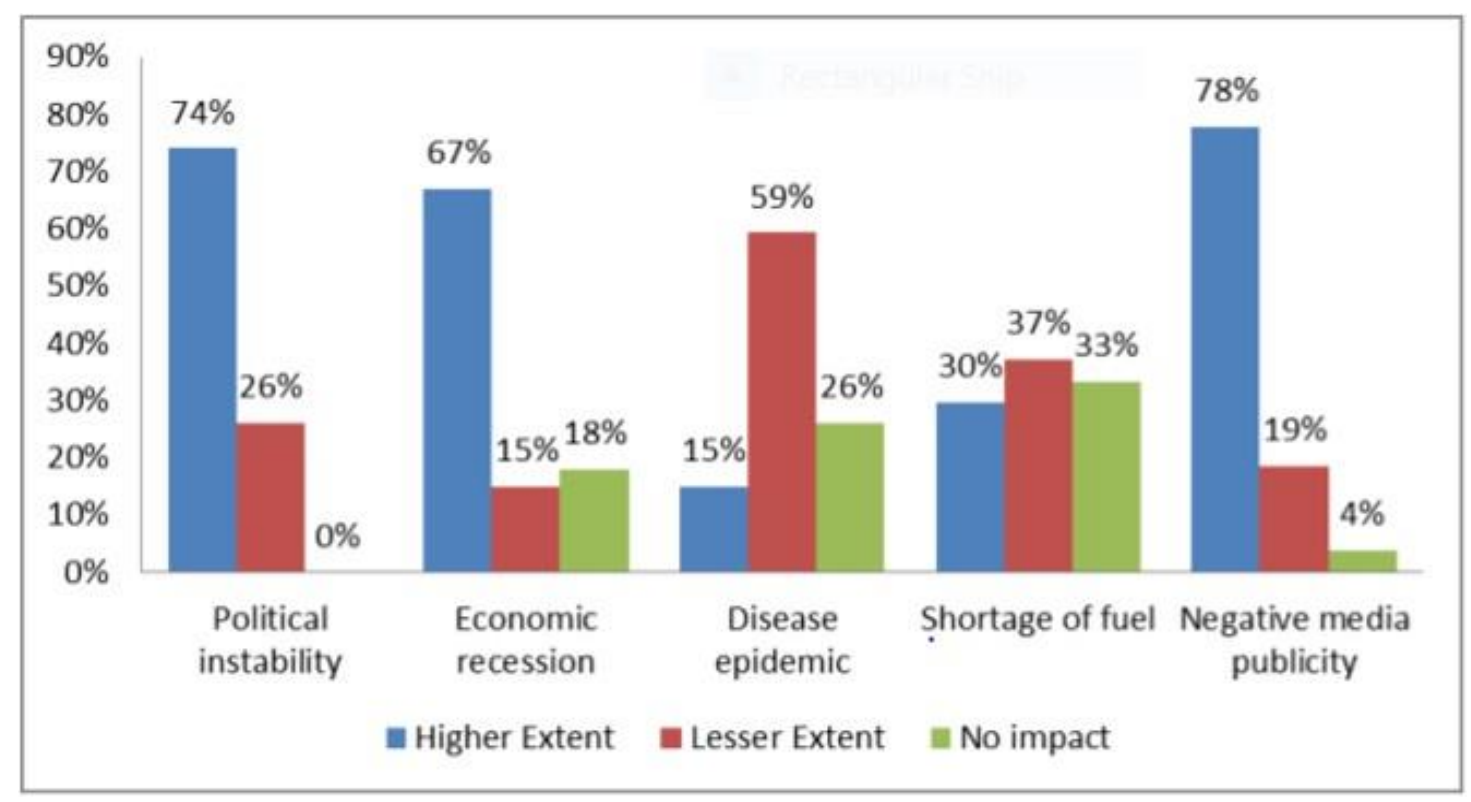

Adapted from Kurambakuwa et al (2015:73)

As indicated by the graph, negative publicity, political instability and economic recession have had a negative impact on the tourism industry (Kurambakuwa et al 2015). Interesting to note in the captioned figure is the fact that in 2015, disease epidemics were to a lesser extend a factor disturbing the Tourism industry. Fast forward to 2020, the factor is now under study as the chief culprit in grounding tourism activities. The above-discussed antecedents weaken the Tourism and Hospitality players from building the organisational slacks that would have become handy in fighting the nCovid pandemic.

\section{Organizational Slack Resources}

Bourgeois (1981: 30) exquisitely defined an organisational slack as a cushion of actual or potential resources, which allow an organisation to adapt successfully to internal pressure for adjustment or to external pressures for change in policy, as well as to initiate changes in strategy with respect to the external environment. Tan and Peng (2003) concurred with Bourgeois and further suggest that organisational slack is utilised within the organisation in four primary ways: 
Firstly, it acts as a buffer to insulate the organization from the unexpected changes in the environment. Tan and Peng (2003) and Bourgeios (1981) noted that the vagaries of the meso and macro environment presented some jolts, which require in-built shocks in form of organizational slack. Secondly, the organizational slack resources can be used to encourage loyalty from the employees to the company by making payments to them in excess of what is required to maintain them in the organization Cyert and March (1963: 36).Thirdly, the slack can be used as resources for conflict resolution in that by using enough resources , any conflict over resources or its potential can be thwarted (Tan \& Peng 2003).Finally Bourgeois (1981) highlighted that organizational slack can be utilized to facilitate the strategic behavior by enabling exploration of new markets and new product development, providing resources for innovation. Sharfman et al, (1988) stated that the purpose of slack is to allow the organization to forego short-term gains in favour of long- term gains. Slack resources are not committed to necessary expenditure, but are built up for future use. Teece, Peteraf and Leih (2016) weighed in with similar sentiments when they examined the impact of slack resources on the organizational agility. Teece, Peteraf and Leih (2016) highlighted that companies can allocate these slack resources to reduce the risk, that is slack resources are "natural hedges" to jolt amelioration. Luo (2017) resonates with earlier scholars and posits a positive direct relationship between availability of slack resources and corporate ambidexterity.

Organisational slack resources are differently categorised by scholars as noted by Bourgeois and Singh (1983) who argued that slack can be differentiated on an ease-of-recovery dimension; that is, a continuum representing how quickly the slack resource can be recovered for potential redeployment. Notably, classification of slack as financial resources dominates the literature, therefore there is need to go beyond focusing on financial aspects when defining slack resources (Geppert, 1996; Lawson, 2001; Meyer, 1982). Luo (2017) asserts that depending on the degree of flexibility, slack resources can be categorized as unabsorbed slack and absorbed slack. Cash and raw material inventory are good examples of unabsorbed slack. Mashina et al (2004) defined unabsorbed slack resources as those that are unused, readily available, and easily redeployed to various use. Absorbed slack refers to those internal resources embedded in firms as excess costs, which has a lower degree of flexibility and cannot be reconfigured for various uses as easy as unabsorbed slack (Bourgeois 1981).These resources include but not limited to skilled labour, flexible, multi-talented labour, excess machine capacity, which provide the firm with exploitative activities and improve firm performance. Luo (2017) highlighted that it is difficult to allocate absorbed slack in the short run, due to its low degree of flexibility.

\section{Strategic agility}

Strategic agility is a phrase formed by two key words, strategy and agility. Goldman's (1995) defined strategic agility as a conscious and weighted answer of the organisation to unpredictable and continuous change in the business environment. Goldman's (1995) revealed that strategic agility enables the organizations to grow and develop in a competitive environment. Doz and Kosonen (2008) cited in Radi and Hawajreh (2013) noted that strategic agility means to make fast turns and being able to transform the company without losing opportunities. Claub, Adebe and Gopgen (2091) concurred with earlier researchers and highlighted that strategic agility enables firms to make rapid changes while preserving their momentum. Strategic agility therefore, allows firms to engage in several renewal changes without the environmental changes as the antecedents. Claub et al (2019) postulates that strategic agility is proactive in nature, a feature that distinguish it from dynamic capabilities. Doz and Kosonen (2008) quoted in Claub et al (2019) mentioned the three particular capabilities that lay ground for strategic agility. These three are strategic sensitivity, leadership unity and resource fluidity. The concept of strategic agility is key in this study as well as its relationship with slack organisational resources 


\section{Methodology}

The study took a positivism epistemological approach dominated by descriptive and correlational tenets. A comprehensive sampling list of vibrant tourism players that spans from Aviation, Hotels \& Restaurants, Tour operators, Car hire companies, Resort centres, Hunting \& Safari operators, Art-Craft \& Curio services was obtained from the Zimbabwe Tourism Authority. A sample of 320 players was randomly drawn from a list 1000 firms through a proportionate stratified randomised criterion to include all the Tourism and Hospitality sub-sectors. A closed ended questionnaire was electronically distributed to the targeted respondents with observation of all due axiological protocols. Initially a pilot study was conducted among 20 selected companies to ensure smooth sailing of the study at full scale. Top management and owners of the businesses were the primary target informants considering the nature of the information requested. In some cases, the primary targeted informants delegated to their appointees. Data collection stretched for eight weeks after initial mailing and remainder phone calls were made. In total, the number of returned instruments were 260, as some were not returned and some returned with limitations such as being incompletely answered. The sample spread is summarised in Table 1 below

\section{Table 1: Sample spread}

\begin{tabular}{|l|c|}
\hline \multicolumn{1}{|c|}{ Tourism Industry sub-sector } & Percent \\
\hline Aviation & $\mathbf{4}$ \\
Care HIRE & $\mathbf{6}$ \\
External Operators & $\mathbf{5}$ \\
Others & $\mathbf{4}$ \\
Hotel and Lodges & $\mathbf{2 5}$ \\
Tour Operators & $\mathbf{9}$ \\
Hunting and Safari & $\mathbf{7}$ \\
Holiday Resorts & $\mathbf{6}$ \\
Culture Sports and Entertainment & $\mathbf{1 0}$ \\
Travel Technology Company & $\mathbf{6}$ \\
Arts Craft and Curio services & $\mathbf{6}$ \\
Cruise Operators & $\mathbf{1 2}$ \\
& $\mathbf{1 0 0}$ \\
\hline
\end{tabular}

The sample was drawn from eleven sub-sectors of the tourism and hospitality industry. The Hotels and Lodges commanded the majority share of the sample, followed by Cruise operators, Culture Sports and Entertainment and Tour operators.

\section{Results and Discussions}

\section{Effects of nCovid 19 on the players}

The study sought to quantify the negative effects brought by the pandemic on the performance indicators of the Tourism and hospitality players. Areas under measurement were nominal demand, which are the general inquiries about the tourism service, effective demand, which are the actual realized sales, revenue changes, raw material supply, working capital availability, operating costs and profit. The percentage bands (e.g. 0-20\%) indicate the extent to which the Tourism businesses were negatively affected on an item under measurement. (A 0-20\% fall means the business is less affected, a $80-100 \%$ fall means a business is heavily affected). An absolute $100 \%$ fall in revenue means a firm record zero revenue at that given period. The figure below is indicating the results of the survey with regard to the given measures. 
Figure 2. Negative Impact of Covid 19 on Tourism Players

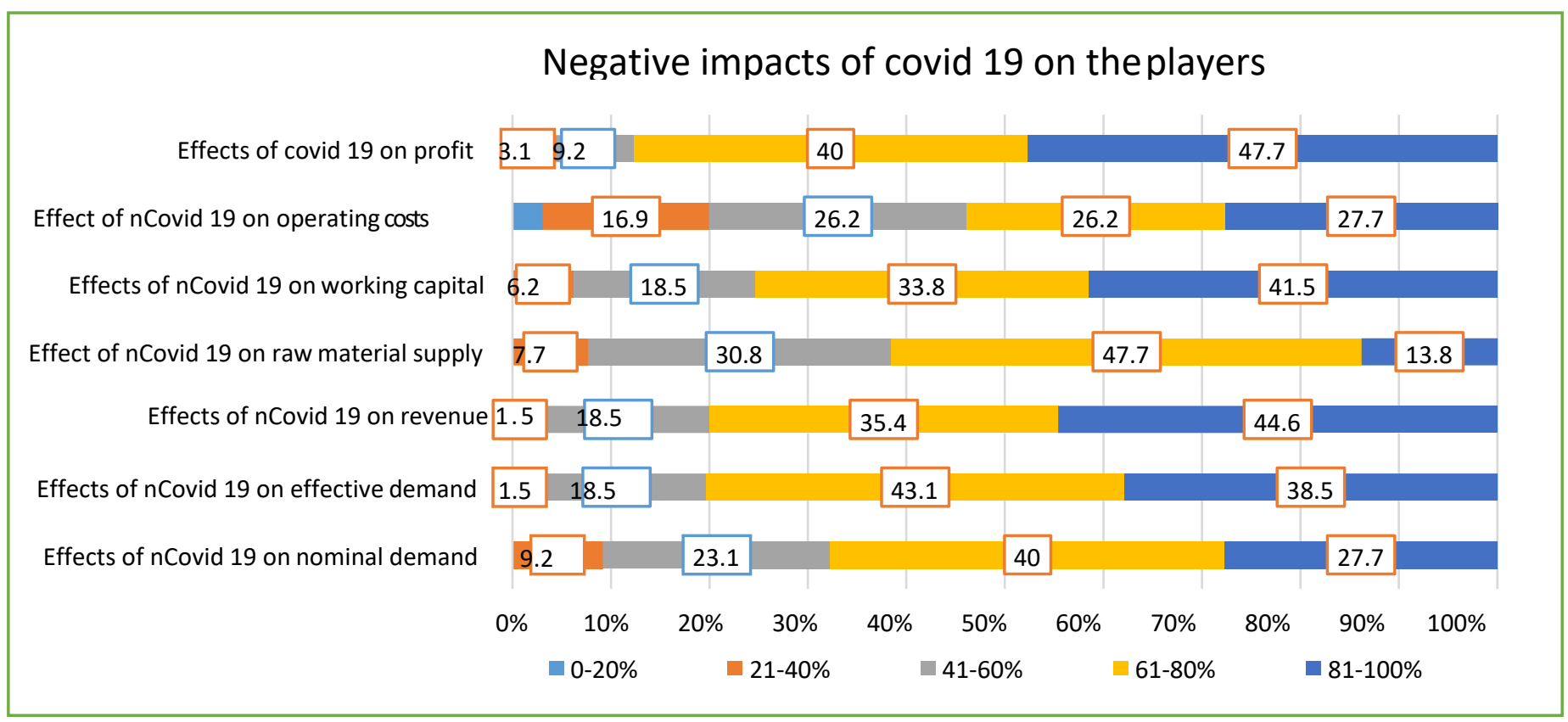

As indicated by the above figure, Tourism and Hospitality players were adversely affected as demand for their services; revenue, profitability and profit were reduced by between $60 \%$ to $100 \%$. Revenue, working capital and profit recorded the heaviest fall. It is interesting to note that the effective demand was heavily affected by the nCovid 19 whilst nominal demand (inquiries) remained comparatively high. Tourists continued to enquire about the services during the covid 19 period under study than they actually purchased the services. The desire to visit and enjoy remained alive despite the threat posed by the lifethreatening pandemic. Comparison of the nominal demand and effective demand statistics bear testimony to this fact. Revenue and working capital were greatly affected as shown by majority of companies indicating $100 \%$ fall in these variables. Profitability fall heavily due to fall in revenue despite a less than proportionate increase in operating costs. Raw material supplies were least affected possibly due to local sourcing or due to raw materials become irrelevant during the lockdown period.

\section{Effects on workers and customers health in the Tourism sector}

Generally, for the period under study (February to September 2020), Zimbabwe recorded few nCovid 19 cases as compared to other countries in the world but regionally, Zimbabwe was the second highest after South Africa. The country had recorded 7672 cases cumulatively as of 18 September 2020 according Zimbabwe Ministry of Health. The health impact of nCovid 19 in the sector was somewhat mild as depicted by the below figure. 
Figure 3. Covid-19 positive cases in the Zimbabwean Tourism and Hospitality Sector

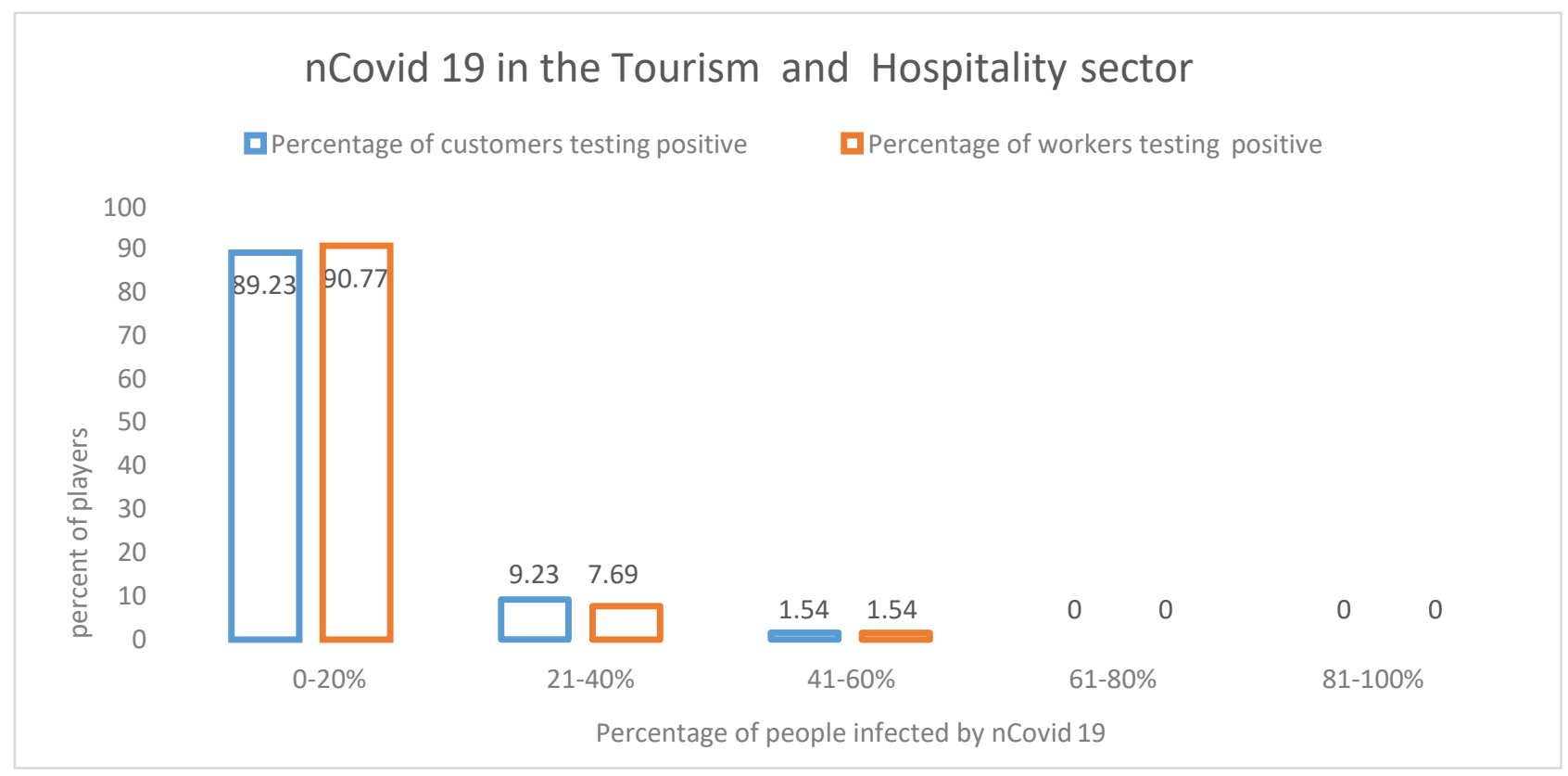

The study sought to establish the number of cases that were recorded in the Tourism and Hospitality industry over the nCovid 19 first peak period (February to September 2020) to quantify the direct impact of the virus on people's health in the sector. The results indicated that $89 \%$ and $91 \%$ of the business recorded $0-20 \%$ infections on clients and workers respectively. $9 \%$ and $7 \%$ of the sampled businesses indicated $21-40 \%$ infections on clients and workers respectively. Impressively, zero companies indicated infections in the $61-100 \%$ category at their work places. The statistics sum up the effectiveness on the part of players and the government in containing the virus during the period under review.

\section{Slack availability in the Tourism subsector}

As discussed in the literature, the availability of slack resources affected an organization's response to changes in the operating environment. As such, the study sought to ascertain the prevalence of slack resources in their various forms across the Tourism industries. The study shows that $55 \%$ of the respondents had available slack resources to mitigate the pandemic's impact on business whilst only $45 \%$ indicated absence of slack resources. Further analysis show that diversification has a contribution to the availability of slack resources for the organisation. The results confirmed that $53 \%$ of the respondents who were in more than 2 subsectors, had available slack resources to fight covid-19 whilst $47 \%$ indicated that they didn't have slack resources despite being in more than 2 subsectors of the Tourism and Hospitality industry

\section{Regression Summary Model}

The study explores the correlation between organisation slack resources availability and the business performance indicators. The results given are as shown in the table below. 
Table 2. Regression summary model

\begin{tabular}{|c|c|c|c|c|}
\hline \multicolumn{5}{|c|}{ Model Summary } \\
\hline Model & $\mathrm{R}$ & R Square & Adjusted R Square & Std. Error of the Estimate \\
\hline 1 & $.564^{\mathrm{a}}$ & .318 & .234 & .440 \\
\hline \multicolumn{5}{|c|}{$\begin{array}{l}\text { a. Predictors: (Constant), Effect on profit, Effects of Covid } 19 \text { on nominal demand, Effect on operating costs, } \\
\text { Effects of Covid } 19 \text { on working capital, Effects on raw material supply, Effects of Covid on effective demand, } \\
\text { Effects of Covid on player revenue }\end{array}$} \\
\hline
\end{tabular}

A regression analysis was done between slack resources and performance indicators.

The findings in the table above of the model summary give R Square value of .318 and Adjusted R Square is .234. The researcher used the Adjusted R. Square since many scholars regard it as more accurate in sharing the predictive power on the dependent variable. As a percentage, performance indicators identified are explained $23.4 \%$ by slack resources. However, the remaining $75.6 \%$ is explained by other variables, which are outside the scope of this study.

\section{Table 3: ANOVA table}

\begin{tabular}{|c|c|c|c|c|c|c|}
\hline \multicolumn{7}{|c|}{ ANOVA $^{\mathrm{a}}$} \\
\hline \multicolumn{2}{|c|}{ Model } & Sum of Squares & Df & Mean Square & $\mathrm{F}$ & Sig. \\
\hline \multirow[t]{3}{*}{1} & Regression & 5.139 & 7 & .734 & 3.799 & $.002^{\mathrm{b}}$ \\
\hline & Residual & 11.015 & 249 & .193 & & \\
\hline & Total & 16.154 & 260 & & & \\
\hline \multicolumn{7}{|c|}{ a. Dependent Variable: Availability of slack resources to fight Covid 19} \\
\hline \multicolumn{7}{|c|}{$\begin{array}{l}\text { b. Predictors: (Constant), Effect on profit, Effects of Covid } 19 \text { on nominal demand, Effect on operating costs, Effects of } \\
\text { Covid } 19 \text { on working capital, Effects on raw material supply, Effects of Covid on effective demand, Effects of Covid } \\
\text { on player revenue }\end{array}$} \\
\hline
\end{tabular}

An ANOVA analysis was done between slack resources and performance indicators (independent) at 95\% confidence level, the F value $=3.799, \mathrm{P}=0.002$ were obtained. Since the $\mathrm{P}$ value 0.002 is less than 0.05 , therefore it is established that there is a linear relationship between slack resources and performance indicators. The presence of slack resources affects the resilience of a business to sustain its performance.

\section{Strategic agility}

Having ascertained the relationship between the slack resources and the performance variables, the research sought the relationship between slack availability and strategic agility. A slack resource versus strategic change cross-tabulation culminated in the below figure 
Figure 4: Strategic agility

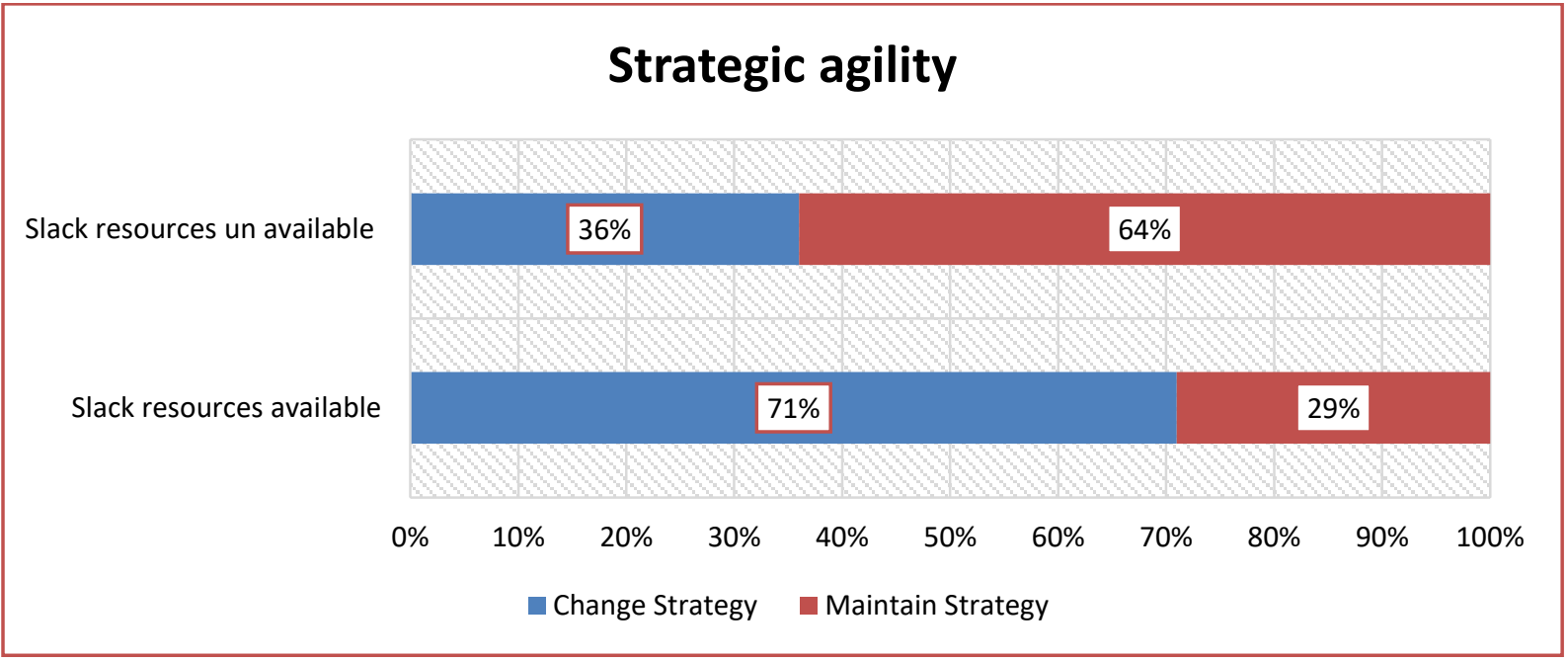

As shown by the figure, businesses with available slack resources mobilized them to change the business strategy in face of Covid 19 . This helped them to maintain high performance in face of nCovid $19.71 \%$ of the businesses with slack resources changed their strategies compared to $36 \%$ who changed strategy despite absence of slack resources. Explanatory notes indicated that, strategic change for slack possessing players was towards related, unrelated diversification, employment of non-contact technologies, creation of new departments, corporate ambidexterity and business model reconfiguration. Explanatory notes on the $36 \%$ who indicated strategic change despite slack resources absence showed bias towards retrenchment strategies such as laying off employees, disposing assets and closing some business units. The explanatory notes showed a sharp contrast in strategic change. Generally, availability of slack resources supported strategic change whilst its unavailability promoted strategic stagnation.

\section{Recommendations}

To mitigate against supply chain disruptions, players were recommended to consider reliance on the local value chains. Buttressing, this notion vertical integration is necessary in tourism for players to have control of raw material supplies as well as associated advantages such as quality control. For example local hotels can vertically integrate backwards to own viable market gardens to reduce fresh produce supply shocks, Based on the study outcome, companies in the Tourism and Hospitality are recommended to put systems in place to capture and store interests (nominal demand) during any crisis. Post crisis, players with inventory of interests can quickly revive demand through follow-ups on nominal demand.

Companies were recommended to create and maintain organisational slack resources to ameliorate unforeseen disruptions. Today's business environment has many disruptions (unforeseen) therefore the need to preserve a reasonable threshold of organisational slack resources in form of both absorbed and unabsorbed slacks. The absorbed slack inform of stored capabilities, excess inventory, highly dynamic staff and unutilized capacities are important in crisis management. Unabsorbed slack resources such as excess liquidity are more redeployable to other uses during a crisis. For example, in this case, procurement of personal protective equipment and investment in non-contact technologies were the possible uses of unabsorbed slack. Tourism and Hospitality players who strategically employed their slack resources gained the trust of the few available customers and gained momentary competitive advantage enough to sail through the difficult period. Lessons from this pandemic must deposit some instinctive stimuli in the organisational memories 
to strategically accumulate organisational slack resources. Furthermore, corporate ambidexterity becomes paramount as a form of an absorbed slack building strategy.

With realization that international tourism was greatly affected by the pandemic, the government through its organs such as Zimbabwe Tourism Authority must increase the marketing of the brand Zimbabwe for the benefit of the cash strapped players in the sector. Relevant authorities must also consider statutory fees holidays and tax breaks as stimulus packages for the beleaguered Tourism and Hospitality players on top of access to affordable credit lines. Faced with disrupted international tourism market, with various source countries taking long to lift travel bans, local players must resort to local and regional markets as their relaunch pads. With general skepticism to travel due to the pandemic overhang and the menacing recurrence as witnessed in other countries, local Tourism and Hospitality players must employ reassuring and safety promising marketing communications to their target audience. Business model re-engineering, service design thinking and basic futurology are some of the requisite strategic moves. It must never be business as usual. Employment of necessary strategies and adjustments has become the new source of competitive advantage in Tourism and Hospitality industry at both company and national level.

\section{Future Studies}

Findings and conclusions of this study set a tonic for future researches in this area. Future researches must focus on determination of the most effective type of organisational slack resource to ameliorate a business environmental jolt such as a pandemic. This study merely looked at the prevalence of slack resources in a company and relation to agility. It is necessary to further study the optimum slack resources thresholds and their impact on the rapidity of resilience. Furthermore, concerning the tourism industry, the typology of corporate strategies employed by firms to manage thorough the crisis need further analysis together with the effects thereof. Surveys on the numbers of permanent business closures, worker retrenchments and corporate anorexia must be conducted to give a clear picture, post the pandemic.

\section{REFERENCES}

Abel S and Roux L P (2017) Tourism on the engine of economic growth in Zimbabwe: Economic Management under hyperinflation 2000-2008

Abu-Radi S and AL- Hawajreh K M (2013) Strategic Agility and Its Impact on the Operations Competitive Capabilities in Jordanian Private Hospitals

Ansari, S. and Millard, S. (2010) 'Organic and acquisitive growth: the role of slack and strategy in organizational performance'. Proceedings from the 2010 Academy of Management Annual Meeting, Montreal, Canada.

Bergh, D., Aguinis, H., Hanke, R. and Perry, J. 2010. 'Resource allocation strategies, shareholder wealth and firm financial performance'. Proceedings from the 2010 Academy of Management Annual Meeting, Montreal, Canada.

Bourgeois III, LJ (1981). On the measurements of organizational slack. Academy of Management Review, 6

Bowen, F (2002) 'Organisational slack and corporate greening: broadening the debate'. British Journal of Management Bromiley, P. (1991) Testing a casual model of corporate risk taking and performance. Academy of Management Journal, Darvishmotevali M and Tajeddini K (2019) UNDERSTANDING ORGANIZATIONAL AGILITY Evidence from the hotel industry in Iran

Gagel G (2017) The Intersection of Organizational Agility and Transformational Leadership: A Literature Review. Academy of Management Annual Meeting Proceedings 2017(1):10895

Glaub T, Adebe M and Dopgen M H (2019) Strategic Agility, Business Model Innovation, and Firm Performance: An Empirical Investigation

Gschwantner S and Hiebl (2016) Management Control Systems and Organizational Ambidexterity

Karambakuwa R, Mauchi F, Chingarande A and Mudavanhu V (2011) the impact of zimbabwe tourism authority initiatives on tourist arrivals in zimbawe (2008 - 2009). Journal od Sustainable Development in Africa

Niven A (2008) Organisational Slack and Industry Level Executive Discretion

Qiu W Rutherford S Mao A and Chu C (2017) The Pandemic and its Impacts. Vol 9-10

This publication is licensed under Creative Commons Attribution CC BY.

http://dx.doi.org/10.29322/IJSRP.10.11.2020.p10785

WWW.ijsrp.org 
Ribeiro M (2020) Immediate Socio-Economic Response to Covid-19 in Zimbabwe. A Framework for Integrated Policy Analysis and Support. United Nations

Richtner A and Ahlstorm P (2006) Influences on organisational slack in new product development projects. International Journal of Innovation Management Vol. 10

Sun Y, Du S and Ding Y(2020) The Relationship between Slack Resources, Resource Bricolage, and Entrepreneurial Opportunity Identification-Based on Resource Opportunity Perspective

Suzuki O (2013) Organizational Slack, Structure, and Learning: A Review of Prior Literature Kwansei Gakuin University Social Sciences Review Vol. 18, 2013

Teece, D., Peteraf, M., \& Leih, S. (2016). Dynamic capabilities and organizational agility: Risk, uncertainty, and strategy in the innovation economy. California Management Review, 58(4), 13-35.

Tembo, B (2017) 'The policy environment around tourism sector in Zimbabwe', Sunday News, Bulawayo, 16 July 2017

Verikios G Sullivan M Stojanovski P, Giesecke1 J and Woo G (2011) Effects global economic effects of pandemic Influenza. Paper prepared for the 14th Annual Conference on Global Economic Analysis, Venice, June 16-18, 2011.

Wefald A J. Katz J P and Rust K G (2010) Organisational Slack, Firm Performance and the Role of Industry, Journal of Management Issue 22

www.medinenet.com

\section{AUTHORS}

First Author - Simbarashe Nhokovedzo, Master of Science in Applied Entrepreneurship, Master of Technology in Strategy and Innovation, Harare Institute of Technology, snhokovedzo@ hit.ac.zw

Second Author - Tawanda Prosper Mushayavanhu, Master of Technology in Strategy and Innovation, Harare Institute of Technology , tmushayavanhu@hit.ac.zw

Third Author - Kudzai Ziki, Master of Technology in Strategy and Innovation, Harare Institute of Technology kudzayiziki@gmail.com

Correspondence Author - Simbarashe Nhokovedzo, snhokovedzo@hit.ac.zw , nhokovedzos@ gmail.com +263 777503296. 